\author{
DEPARTMENT OF THE INTERIOR \\ UNITED STATES GEOLOGICAL SURVEY
}

\title{
AEROMAGNETIC MAP OF THE TROUT CREEK QUADRANGLE SANDERS AND LINCOLN COUNTIES, MONTANA AND SHOSHONE COUNTY, IDAHO
}

\author{
GEOPHYSICAL INVESTIGATIONS \\ MAP GP-685
}

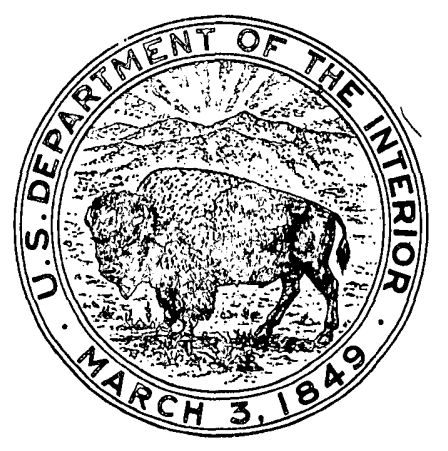

PUBLISHED BY THE U. S. GEOLOGICAL SURVEY WASHINGTON, D.C. 